\title{
PENGGUNAAN ALAT PERAGA DALAM PEMBELAJARAN PKN PADA SISWA KELAS V SDN SAWAH III GIRISEKAR KECAMATAN PANGGANG KABUPATEN GUNUNG KIDUL
}

\author{
Oleh \\ Nuryati*, Sri Hastuti Retna Yuliasih* \\ Universitas Cokroaminoto Yogyakarta
}

\begin{abstract}
Abstrak
Bidang studi PKn Sekolah Dasar adalah bidanga studi yang penyajian materinya harus diupayakan dengan menggunakan alat peraga. Hal ini sebagai upaya memberikan kesan realistis terhadap siswa dan sekaligus bertujuan untuk menghilangkan kesan verbalisme dalam pembelajarannya. Penelitian ini bertujuan untuk mengetahui hasil belajar PKn pada siswa kelas V SDN Sawah III Grisekar Panggang sebelum dan sesudah diadakan tindakan dengan menggunakan alat peraga. Metode penelitian ini menggunakan metode Penelitian Tindakan Kelas. Sumber data utama penelitian adalah siswa kelas V SDN Sawah III Girisekar Panggang Tahun Ajaran 2011/2012. Sebanyak 26 orang siswa. Data dikumpulkan dengan jalan tes. Analisis data yang digunakan adalah analisis data statistik.

Hasil belajar PKn siswa kelas V di SDN Sawah III Girisekar Kecamatan Panggang, terutama pada aspek kognitif (kemampuan menguasai konsep), sebelum diadakan tindakan hanya $19 \%$ yang menguasai konsep. Sesudah diadakan tindakan dengan menggunakan alat peraga pembelajaran, terjadi peningkatan menjadi $61 \%$ siswa yang menguasai onsep PKn, khususnya mengenai pokok bahasan tanggung jawab. Sikap bertanggungjawab siswa kelas V SDN Sawah III Girisekar Panggang sebelum dilakukan tindakan hanya 11\% siswa yang berani bertanya di dalam kelas. Dan sesudah diadakan tindakan pembelajaran dengan alat peraga, maka kemampuan bertanya siswa meningkat menjadi 53\% mereka kritis terhadap materi pelajaran yang diajarkan oleh gurunya di kelas. Sebelum diadakan tindakan pembelajaran di kelas dengan alat peraga, kemampuan menggambarkan perilaku bertanggungjawab siswa kelas V SDN Sawah III Girisekar Panggang hanya 46\% yang bisa menggambarkan, dan sesudah diadakan tindakan pembelajaran menggunakan alat peraga meningkat menjadi $84 \%$ siswa mampu menggambarkan bentuk perilaku bertanggungjawab.

Kata Kunci: Pembelajaran PKn, Alat Peraga, Kelas V SDn Sawah III Girisekar Panggang, Penelitian Tindakan Kelas (PTK)
\end{abstract}

Kata Kunci: Alat Peraga, Pembelajaran PKn, Penelitian Tindakan Kelas. 


\section{Pendahuluan}

Praktek pengajaran yang dilaksanakan oleh para guru, akan banyak dijumpai persoalan yang beraneka ragam. Keanekaragaman itu terjadi dikarenakan berbagai macam faktor. Faktorfaktor ini antara lain tingkah laku guru, siswa, dan situasi kelas. Hal itu disebabkan oleh peranan dan fungsi guru dalam pembelajaran yang menjadi inti penyelenggaraan pendidikan formal memberi warna pada bentuk dan proses pengajaran.

Pandangan guru tentang mengajar dan kemampuan mengajar yang dimiliki oleh setiap guru berbeda-beda. Perbedaan itu memberi pengaruh kepada munculnya keanekaragaman dalam proses pengajaran. Oleh karena itu, guru sepatutnya mampu memcari startegi yang dipandang dapat menciptakan ilklim kelas yang kondusif, sehingga tujuan pengajaran dapat tercapai secara lebih efektif serta hasil belajar dapat lebih ditingkatkan. Bidang studi Pendidikan Kewarganegaraan (PKn) pada pelaksanaannya haruslah diupayakan dengan kondisi pembelajaran yang kondusif dalam arti suatu pembelajaran yang aktif, kreatif, efektif, bahkan inovatif. Untuk mencipatakan kondisi pembelajaran seperti itu, maka perlu ada usaha untuk memaksimalkannya. Usaha tersebut di anataranya dengan cara memanfaatkan berbagai sarana dan prasarana yang ada, bahkan bila dipandang perlu seorang guru dapat membuat sendiri alat peraga PKn yang diperlukan, sehingga pada gilirannya pembelajaran PKn itu tidaklah berupa penyampaian informasi yang cukup hanya didiktekan saja. Sebab, perlu diketahui bahwa materi Pkn bukanlah syair atau sajak yang hanya disampaikan melalui informasi saja, melainkan harus diupayakan suatu pembuktian dalam upaya menghindari verbalisme. Seperti yang telah dikemukakan oleh Piaget, bahwa perkembangan kognitif/pengetahuan terbagi atas empat tahapan, yaitu:

1. Periode sensori motor, 0-2 tahun

2. Periode pra-operasional, 3-7 tahun

3. Periode operasional konkrit, 9-14 tahun

4. Periode operasional formal, 14 tahun ke atas.

Dilihat dari periodesasi perkembangan berfikir tersebut, siswa sekolah dasar secara teoritis berada pada tahap operasional konkrit. Pada periode ini ditandai oleh terjadinya cara berfikir logis yang dikaitkan dengan setting nyata. Dengan dasar itulah, pembelajaran PKn di SD sebaiknya diarahkan pada perangsangan cara berfikir logis. Relevan dengan kecenderungan 
proses berfikir pembelajaran tersebut, Bell Gredler (1986) sebagaimana dikutip oleh Udin, SW. Dkk (1992:34), mengidentifikasikan pokok dalam pemblajaran, yaitu:

1. Mengembangkan keterampilan "bagaimana belajar" atau "how to learn skills".

2. Memberi kemudahan "alih proses belajar" atau "transfer of learning"

3. Membelajarkan proses pemecahan masalah atau "teaching problem solving"

Hal ini menunjukkan bahwa media (alat bantu) belajar selain dapat meningkatkan motivasi dan kreativitas siswa juga dapat membantu memberikan kemudahan bagi siswa untuk memahami pelajaran. Hanya saja kecenderungan yang terjadi di lapangan membuktikan pula bahwa penggunaan alat peraga PKn baik yang bersifat langsung maupun yang tiruan/buatan secara empirik belumlah cukup teroperasionalisasikan di sekolah-sekolah dasar pada umumnya. Kenyataan ini dialami pula di SD Negeri Sawah III Girisekar Panggang tempat pelaksanaan penelitian tindakan kelas. Secara umum di SD Negeri Sawah III Giri Sekar Panggang tempat pelaksanaan penelitian yang terletak di daerah pegunungan memang masih membutuhkan sarana dan prasarana yang mendukung. Dari hasil observasi yang dilakukan peneliti di sekolah yang dijadikan penelitian, hasil nilai tes PKn menunjukkan angka yang kurang begitu menggembirakan. Untuk pengambilan data awal yang dijadikan sebagai bahan acuan ataupun bahan pertimbangan abtara sebelum dilaksanakan tidakan dan sesudah dilaksanakan tindakan adalah dengan mengambil salah satu hasil tes. Bertolak dari data tersebut, maka peneliti memandang perlu diadakannya suatu perbaikan dalam masalah pembelajaran. Oleh karenanya, untuk mengetahui permasalahan tersebut secara tepat, maka sebagai upaya perbaikan pelaksanaan pembelajaran PKn di Sekolah Dasar dilakukan melalui Penelitian Tindakan Kelas (PTK). Tujuan penelitian ini adalah untuk mengetahui hasil belajar PKn siswa kelas V SD Negeri Sawah III Girisekar Kecamatan Panggang sebelum dan sesudah diadakan tindakan dengan menggunakan alat peraga tahun ajaran 2011/2012 dan untuk mengetahui kemauan bertanya siswa kelas V SD Negeri Sawah III Girisekar Panggang selama proses pembelajaran PKn dengan menggunakan alat peraga. Hasil penelitian ini diharapkan dapat berguna bagi pengembangan ilmu pendidikan, khususnya dalam Pendidikan Kewarganegaraan, terutama manfaat penggunaan alat peraga dalam pembelajaran PKn di Sekolah Dasar. Selain itu, penelitian ini diharapkan juga dapat berguna bagi guru PKn dan siswa kelas V SDN Sawah III, terutama manfaat penggunaan alat peraga dalam pembelajaran PKn. 


\section{Metode Penelitian}

Penelitian tindakan kelas tentang "Penggunaan Alat Peraga dalam Pembelajaran PKn" ini dilaksanakan di SDN Sawah III Girisekar Kecamatan Panggang, khususnya pada siswa kelas V pada tahun ajaran 2011/2012 yang jumlah siswanya 20 orang terdiri dari 10 orang siswa lakilaki dan 10 orang siswa perempuan. Penelitian ini dilaksanakan selama lebih kurang dua bulan sejak bulan Februri sampai dengan Maret 2012. Alasan dipilihnya menggunakan jenis Penelitian Tindakan Kelas adalah karena dalam penelitian ini (PTK) lebih terfokus pada permasalahan yang ada di dalam kelas dan dialami langsung oleh guru. Sebab, bagi seorang guru sering menemukan berbagai macam masalah, terutama mengenai bagaimana memberikan materi pelajaran agar dapat terpahami oleh siswa dengan cepat dan tepat atau mengenai kondisi kelas yang kurang kondusif, bahkan terkadang guru kurang menyadari penggunaan metde mengajarnya kurang sesuai. Hampir semua guru, terutama guru SDN, pernah merasakan kesulitan seperti itu. Berkalikali ia mencoba dengan menggunakan metode ataupun strategi yang dianggap tepat, namun hasilnya terkadang kurang menggembirakan. Oleh karena itulah, maka melalui Penelitian Tindakan Kelas ini diharapkan dapat terpecahkan problem pembelajaran yang dialami oleh guru.

Dalam Penelitian Tindakan Kelas ini penulis metode deskriptif. Winarno Surakhmad (1990:140) mengatakan bahwa yang dimaksud dengan metode deskriptif adalah "suatu metode yang menggambarkan kegiatan atau usaha untuk memecahkan masalah yang ada pada waktu penelitian dilaksanakan dengan jalan mengumpulkan data serta menyusunnya secara sistematis kemudian dianalisis untuk mendapatkan pemecahan masalah." Instrumen yang digunakan untuk pengumpulan data dalam penelitian ini adalah: (1) tes tertulis yang diberikan bertujuan untuk memperoleh informasi mengenai kemampuan siswa dalam menyelesaikan materi PKn; (2) observasi kelas, dilakukan dengan maksud untuk memperoleh gambaran baik bersifat umum maupun khusus berkenaan dengan aspek-aspek proses penggunaan alat peraga dalam pembelajaran PKn.

Prosedur Penelitian Tindakan Kelas ini terdiri dari dua siklus. Tiap siklus dilaksanakan sesuai dengan perubahan yang diinginkan, seperti apa yang telah didesain dalam faktor yang diselidiki. Untuk dapat melihat sejauh mana siswa mampu memahami materi PKn secara optimal melalui penggunaan alat peraga dalam memberikan pelajarannya, maka diberikanlah tes diagnosa yang berfungsi sebagai evaluasi awal. Sedangkan observasi awal dilakukan untuk dapat mengetahui tindakan yang tepat yang diberikan dalam rangka meningkatkan pemahaman siswa 
terhadap materi PKn tersebut. Adapaun langkah-langkah dalam Penelitian Tindakan Kelas adalah: (1) perencanaan; (2) pelaksanaan tindakan; (3) observasi; dan (4) refleksi dalam setiap siklus yang dilakukan secara berulang. Teknik analisis yang digunakan ada yang bersifat kualitatif dan kuantitatif. Data yang diperoleh dikategorikan dan diklasifikasikan berdasarkan analisis kaitan logisnya kemudian ditafsirkan dan disajikan secara aktual dan sistematis dalam keseluruhan permasalahan dan kegiatan penelitian. Selanjutnya, untuk menganalisis data hasi; tindakan yang dilakukan, disajikan secara bertahap sesuai dengan siklus yang telah dilakukan serta jenis dan bentuk action yang telah dilakukan beserta efek yang ditimbulkannya. Prosedur pengolahan dan analisis data dilaksanakan mengacu kepada pola pengolahan data dari Hopkin (dalam Kanda, 2001:55) yang dilakukan melalui tahap-tahap sebagai berikut: pengumpulan data, validasi data, dan interpretasi.

\section{Hasil Penelitian dan Pembahsan}

\section{Perencanaan Tindakan}

Pada tahap ini peneliti merumuskan Rencana Pembelajaran (RP) untuk bidang studi PKn untuk ditindaklanjuti pembelajaran yang menerapkan pada penggunaan alat peraga dan media peraga tiga dimensi untuk kegiatan demonstrasi. Materi yang diberikan adalah mengenai tanggung jawab. Standar kompetensi adalah bertanggung jawab dalam melaksanakan hak dan kewajiban (tindakan I) dan bertanggung jawab terhadap perbatan yang dilakukan (tindakan II).

2. Pelaksanaan Tindakan

Pelaksanaan tindakan dilaksanakan sesuai dengan rumusan perencanaan tindakan penelitian yang telah dipersiapkan sepertiyang telah diuraikan sebelumnya. Pelaksanaan tindakan penelitian menekankan pada penggunaan alat peraga dalam pembelajaran PKn sebagai upaya meningkatkan pemahaman materi PKn. Peneliti yang sekaligus merangkap sebagai guru kelas dalam pelaksanaan untuk Tindakan Pertama menggunakan alat peraga dengan menekankan metode demonstrasi tanya jawab. Dalam pelaksanaan tindakan guru/peneliti secara sengaja tidak membertahukan kepada siswa bahwa saat itu sedang diadakan penelitian.

1) Tindakan Pertama

Proses pelaksanaan tindakan pertama adalah mengaktualisasikan skenario pembelajaran yang telah dipersiapkan sebelumnya. Untuk tindakan pertama mengambil sub pokok bahasan "Bertanggung Jawab dalam Melaksanakan Hak dan Kewajiban”. Pencapaian tujuan untuk setiap 
ranah (kognitif/pengetahuan, afektif/sikap, dan psikomotorik/keterampilan) diharapkan dapat tercapai dengan cara memberikan soal dan tugas yang sesuai dengan maksud dan tujuan. Ranah kognitif/pengetahuan diharapkan dapat tercapai dengan jalan memberikan butir soal yang harus dijawab oleh siswa mengenai tanggung jawab. Untuk ranah afektif/sikap dapat diketahui dengan cara melihat sikap kritis atau kemauan bertanya siswa selama proses pembelajaran, Adapun masalah pertanyaannya baik itu masalah pelajaran maupun mengenai cara pengerjaan soal atau yang lainnya. Sedangkan untuk ranah psikomotorik/keterampilan dilihat terutama dari teknik mengkomunikasikan peralatan yang dibutuhkan dalam membuat telepon mainan serta bentuk gambar. Siswa disuruh menggambarkan telepon mainan yang terbuat dari kaleng susu dilengkapi dengan bagian-bagiannya.

Perolehan Nilai pada siklus I sebagai berikut:

Rerata konsep $=5: 26=0,19$

Rerata menggunakan alat $=16: 26=0,61$

Rerata menyiapkan alat $=10: 26=0,38$

Rerata gambar dengan keterangan $=12: 26=0,46$.

Berdasarkan data tersebut, ditunjukkan bahwa tingkat penguasaan konsep masih perlu mendapatkan perhatian cukup. Hanya sekitar 19\% dari jumlah siswa yang mampu menguasai konsep, sedangkan $81 \%$ masih perlu mendapatkan perhatian yang serius.

Untuk kecakapan dalam penggunaan alat sudah menampakkan hasil yang cukup bagus. Data menunjukkan $61 \%$ sudah mampu menggunakan alat. Artinya, lebih dari separuh siswa sudah mampu menggunakan alat meskipun hanya dalam bayangan saja. Dalam tahap meyiapkan alat baru $38 \%$ dari jumlah siswa yang mampu menyiapkan. Hal ini pun sama seperti menggunakan alat yakni dalam bayangan saja. Sisanya sekitar $62 \%$ dari jumlah siswa masih perlu mendapat bimbingan. Untuk penguasaan ranah kognitif masih berada di bawah 50\% sehingga hal ini perlu mendapat peningkatan yang lebih lanjut pada tahap berikutnya. Selain itu, data menunjukkan bahwa siswa pada umumnya belum dapat menggambar dengan membubuhkan keterangan secara tepat. Hanya $46 \%$ dari jumlah siswa yang mampu menggambar diberi keterangan, sehingga dengan demikian untuk ranah psikomotorik/keterampilan pun dalam hal ini mengkomunikasikan gambar, masih berada di bawah 50\% sehingga para siswa perlu diberi latihan dan penerangan untuk tindakan selanjutnya. 
Tabel 1. Frekuensi Kemauan Bertanya Siswa pada Siklus I

\begin{tabular}{|c|c|c|}
\hline Nomor Siswa & Konsep & Teknis/Non Teknis \\
\hline 1 & & V \\
\hline 2 & & V \\
\hline 3 & & V \\
\hline Jumlah & 0 & 3 \\
\hline
\end{tabular}

Keterangan:

Teknis = pelajaran

Non teknis $=$ non pelajaran

Data Tabel 1 menunjukkan bahwa pada siklus atau tindakan pertama ini sikap kritis siswa belum menampakkan jumlah yang signifikan. Selama proses belajar mengajar hanya 3 orang atau $11 \%$ yang berani menanyakan sesuatu, meskipun bila dari jenis pertanyaannya semuanya bukan mengenai pelajaran melainkan masalah bagaimana cara mengerjakan soal atau yang lainnya. Namun demikian, bila dibandingkan dengan sebelum tindakan, hal ini sudah ada kemajuan. Pada waktu sebelum tindakan situasi proses belajar mengajar sangat psaif. Dari mulai pembelajaran sampai akhir, tidak ada seorang pun yang mau atau berani untuk mengungkapkan pendapat atau menanyakan sesuatu. Padahal mereka sudah diberikan kesempatan untuk hal tersebut. Mereka cenderung diam, dengan kata lain situasi pembelajaran bernuansa DDCH (duduk dengar catat hafal) masih sangat kentara.

2) Tindakan Kedua

Proses pelaksanaan tindakan kedua adalah mengaktualisasikan skenario pembelajaran yang telah dipersiapkan sebelumnya, yang merupakan hasil dari refleksi I. Untuk tindakan kedua mengambil sub pokok bahasan “Bertanggung Jawab terhadap Perbuatan yang Dilakukan”. Pada tindakan kedua ini penekanan pada penggunaan alat tiga dimensi untuk melaksanakan percobaan, serta menggunakan persiapan mengajar dengan mencantumkan peta konsep pembelajaran. Pencapaian tujuan untuk setiap ranah (kognitif/pengetahuan, afektif/sikap, dan psikomotorik/keterampilan) diharapkan dapat tercapai dengan cara memberikan soal dan tugas yang sesuai dengan maksud dan tujuan. Ranah kognitif/pengetahuan diharapkan dapat tercapai dengan jalan memberikan butir soal yang harus dijawab oleh siswa mengenai bertanggung jawab terhadap perbuatan yang dilakukan. Untuk ranah afektif/sikap dapat diketahui dengan cara melihat sikap kritis atau kemauan bertanya siswa selama proses pembelajaran, Adapun masalah pertanyaannya baik itu masalah pelajaran maupun mengenai cara pengerjaan soal atau yang lainnya. Sedangkan untuk ranah psikomotorik/keterampilan dilihat terutama dari teknik 
mengkomunikasikan gambar. Siswa disuruh menggambarkan jam dinding dan jam beker dilengkapi dengan keterangan gambar serta melihat unsur perbandingan dari kedua gambar tersebut.

Perolehan Nilai pada siklus II sebagai berikut:

Rerata konsep $=16: 26=0,61$

Rerata menggunakan alat $=22: 26=0,84$

Rerata menyiapkan alat $=14: 26=0,53$

Berdasarkan data tersebut, ditunjukkan bahwa tingkat pengusaan konsep sudah menunjukkan peningkatan bila dibandingkan tindakan I. Sudah $61 \%$ dari jumlah siswa yang mampu menguasai konsep, sedangkan 59\% masih perlu mendapatkan perhatian yang serius.

Seperti pada tindakan pertama, aspek afektif/sikap pada tindakan kedua juga masih mengenai kemauan bertanya siswa selama proses belajar mengajar. Dalam siklus kedua, kemauan bertanya siswa sudah mulai ada peningkatan, yakni menjadi 10 orang siswa atau sekitar $38 \%$ yang mau bertanya. Pertanyaan yang dilontarkan hampir sama pada siklus I yaitu mengenai non materi. Namun meskipun demikian sikap siswa sudah mulai ada perubahan yang ditandai dengan bertambahnya siswa yang mau bertanya.

Tabel 2. Frekuensi Kemauan Bertanya Siswa pada Siklus II

\begin{tabular}{|c|c|c|}
\hline Nomor Siswa & Konsep & Teknis/Non Teknis \\
\hline 1 & & $\mathrm{~V}$ \\
\hline 2 & & $\mathrm{~V}$ \\
\hline 3 & & $\mathrm{~V}$ \\
\hline 4 & & $\mathrm{~V}$ \\
\hline 5 & & $\mathrm{~V}$ \\
\hline 6 & & $\mathrm{~V}$ \\
\hline 7 & & $\mathrm{~V}$ \\
\hline 8 & & $\mathrm{~V}$ \\
\hline 9 & & $\mathrm{~V}$ \\
\hline 10 & & 10 \\
\hline Jumlah & & \\
\hline
\end{tabular}

\section{Keterangan:}

Teknis $=$ pelajaran

Non teknis $=$ non pelajaran 
Pada tahap kecakapan dalam penggunaan alat sudah menampakkan hasil yang cukup bagus. Hampir $84 \%$ sudah mampu menggunakan alat, sedangkan dalam tahap menyiapkan alat sudah mampu mencapai angka 53\% dari jumlah siswa yang ada. Hal ini, menunjukkan bahwa para siswa sudah mulai meningkat kemapuan mengkomunikasikan sesuatu dalam bentuk tulisan. Dalam penguasaan ranah psikomotorik/keterampilan mengkomunikasikan gamabr, terdapat dau bagian. Bagian pertama mengenai perbandingan gambar, sedangkan yang kedua mengenai menggunakan keterangan. Untuk keterampilan mengkomunikasikan gambar dengan menggunakan perbandingan gambar masih jauh dari cukup. Dari data yang ada hanya 5 orang atau sekitar 19\% siswa yang perbandingan gambaranya agak sesuai. Dalam hal ini siswa belum mempergunakan rumus perbandingan secara matematis. Standar yang digunakan hanya berdasarkan kesesuaian gambar dengan perbandingan sederhana. Pada bagian kedua dari jumlah siswa yang ada, 22 orang atau 84\% sudah dapat menggambarkan dengan menyertakan keterangan gambar. Kecenderungan yang terjadi, dalam tahap pengamatannya para siswa masih sangat sederhana. Tahapan yang mereka lakukan dalam menggambar adalah mengamati, lalu mengamati, kemudian menggambar.

Perolehan nilai menggambar pada siklus II

Perbandingan yang sesuai $=5: 26=0,19$

Menggunakan keterangan $=22: 26=0,84$

Data tersebut menunjukkan bahwa pada umumnya siswa masih belum dapat menggambar dengan membubuhkan keterangan secara tepat. Hanya $46 \%$ dari jumlah siswa yang mampu menggambar yang diberi keterangan. Sehingga dengan demikian untuk ranah psikomotorik/keterampilan pun dalam hal ini mengkomunikasikan gambar, masih berada di bawah $50 \%$ sehingga para siswa perlu diberi latihan dan penerangan untuk tindakan berikutnya terutama dalam hal perbandingan suatu obyek/gambar. Berdasarkan penelitian yang telah dilakukan, maka dapat disimpulkan bahwa penggunaan alat peraga dalam pembelajaran PKn dapat memperkecil jumlah siswa yang kurang pemahamannya terhadap materi pelajaran pada setiap putaran (siklus). Dilihat dari rata-rata prosentase nilai kelas selama dua putaran, PTK ini ternyata dapat meningkatkan rata-rata hasil belajar siswa pada bidang studi PKn. 


\section{Kesimpulan}

Berdasarkan hasil penelitian dan pembahasan, serta seuai dengan perumusan masalah dan tujuan penelitian, maka kesimpulan dari penelitian ini adalah sebagai berikut:

1. Hasil belajar Pkn siswa kelas V di SDN Sawah III Girisekar Kecamatan Panggang, terutama pada aspek kognitif (kemampuan menguasai konsep), sebelum diadakan tindakan hanya 19\% yang menguasai konsep. Sesudah diadakan tindakan dengan menggunakan alat peraga pembelajaran, terjadi peningkatan menjadi $61 \%$ siswa yang menguasai konsep PKn, khususnya mengenai materi tanggung jawab.

2. Sikap bertanggung jawab siswa kelas V SDN Sawah III Girisekar sebelum dilakukan tindakan hanya $11 \%$ siswa yang berani bertanya di dalam kelas. Dan sesudah diadakan tindakan pembelajaran dengan menggunakan alat peraga, maka kemauan bertanya siswa meningkat menjadi 53\% mereka kritis terhadap materi pelajarn yang dijarkan gurunya di kelas.

3. Sebelum diadakan tindakan pembelajaran dengan alat peraga, kemampuan menggambarkan perilaku bertanggung jawab siswa kelas V SDN Sawah III Girisekar hanya 46\% yang bisa menggambarkan, dan sesudah diadakan tindakan pembelajaran menggunakan alat peraga meningkat menjadi 84\% siswa mampu menggambarkan bentuk perilaku tanggung jawab.

Berdasarkan hasil kesimpulan diperoleh keterangan bahwa pembelajaran PKn dengan menggunakan alat peraga dipandang cenderung lebih baik dibandingkan dengan yang tidak menggunakan alat peraga. Oleh karena itu berarti alat peraga dapat membantu meningkatkan pemahaman siswa terhadap materi pelajaran PKn. Dengan demikian, saran yang perlu disampaikan di antaranya adalah:

1. Bagi Kepala Sekolah, mengingat kedudukan alat peraga adalah penting dalam memperlancar pembelajaran PKn dan mata pelajaran lainnya, maka sekolah perlu menyediakan alat peraga pembelajaran tersebut selengkap mungkin.

2. Bagi guru PKn, penggunaan alat peraga adalah mutlak perlu dilaksanakan agar siswa dapat dengan mudah memahami materi pelajaran yang disampaikan.

3. Bagi siswa, belajar PKn dengan menggunakan alat peraga bermanfaat dalam memehami materi pelajaran, sehingga sudah saatnya siswa menggunakan alat peraga tersebut. 


\section{Daftar Pustaka}

Asep Heri Hermawan, dkk. (2003). Pengembangan Kurikulum dan Pembelajaran. Jakarta: Universitas Terbuka.

Asmawi Zainul dan Agus Mulyana. (2003). Tes dan Asesmen di SD. Jakarta: Universitas Terbuka.

A.T.Rusyan. (1999). Meningkatkan Mutu Kegiatan dalam Proses Belajar Mengajar di Sekolah Dasar. Jakarta: PT. Kartanegara

Depdikbud. (2004). Kurikulum Pendidikan Dasar, GBPP 2004 (KBK) Kelas V SD. Jakarta: Depdikbud.

Dinn Wahyudin, dkk. (2003). Pengantar Pendidikan. Jakarta: Universitas Terbuka.

Gunawan Undang, dkk. (1998). Peningkatan Mutu PBM SD. Bandung: Cv. Siger Tengah.

Ibrahim WS, dkk. (2001). Pendidikan Pancasila dan Kewarganegaraan Bernuansa Budi Pekerti untuk Sekolah Dasar Kelas V. Bandung: Sarana Pncakarya.

J.R.E. Kaligis dan Damodjo. (1992). Pendidikan Pancasila. Jakarta:Depdikbud.

Kasihani Kasbolah E.S. (1999). Penelitian Tindakan Kelas. Jakarta: Depdikbud.

Mulyati Arifin. (2000). Modul Peningkatan Kemmapuan Guru dalam Proses Belajar Mengajar.Bandung: Sinar Baru.

Nana Sudjana. (1989). Cara Belajar Siswa Aktif dalam Proses Belajar Mengajar. Bandung: Sinar Baru.

Nana Suparna, dkk. (2006). Pendidikan Kewarganegaraan untuk SD Kelas V. Jakarta:Erlangga.

Sardiman A.M. (1987). Interaksi dan Motivasi Belajar Mnegajar. Jakarta: Rajawali Press, 1987.

Srini M. Iskandar dan Eddy M. Hidayat. (1997). Pendidikan Pancasila dan Kewarganegaraan. Jakarta: Depdikbud.

Suharsimi Arikunto. (2001). Dasar-dasar Evaluasi Pendidikan. Jakarta: Bumi Aksara.

Udin S.W. (1992) Materi Pokko Strategi Belajar Mengajar PKn. Jakarta: Depdikbud.

Wardani, dkk. (2004). Pemantapan Kemmapuan Profesional (Panduan). Jakarta: Universitas Terbuka. 